\title{
Challenges for Serology-Based Characterization of Foot-and-Mouth Disease Outbreaks in Endemic Areas; Identification of Two Separate Lineages of Serotype O FMDV in Uganda in 2011
}

Namatovu, A.; Belsham, Graham; Ayebazibwe, C.; Dhikusooka, M. T.; Wekesa, S. N.; Siegismund, H. R.; Muwanika, V. B.; Tjørnehøj, Kirsten

\section{Published in:}

Transboundary and Emerging Diseases

Link to article, DOI:

10.1111/tbed.12170

Publication date:

2015

Document Version

Peer reviewed version

Link back to DTU Orbit

Citation $(A P A)$ :

Namatovu, A., Belsham, G., Ayebazibwe, C., Dhikusooka, M. T., Wekesa, S. N., Siegismund, H. R., Muwanika, V. B., \& Tjørnehøj, K. (2015). Challenges for Serology-Based Characterization of Foot-and-Mouth Disease Outbreaks in Endemic Areas; Identification of Two Separate Lineages of Serotype O FMDV in Uganda in 2011. Transboundary and Emerging Diseases, 62(5), 522-534. https://doi.org/10.1111/tbed.12170

\section{General rights}

Copyright and moral rights for the publications made accessible in the public portal are retained by the authors and/or other copyright owners and it is a condition of accessing publications that users recognise and abide by the legal requirements associated with these rights.

- Users may download and print one copy of any publication from the public portal for the purpose of private study or research.

- You may not further distribute the material or use it for any profit-making activity or commercial gain

- You may freely distribute the URL identifying the publication in the public portal 
1 Challenges for serology-based characterization of foot-and-mouth disease outbreaks in

endemic areas; identification of two separate lineages of serotype O FMDV in Uganda in

A. Namatovu ${ }^{1,2}$, G. J. Belsham ${ }^{3}$, C. Ayebazibwe ${ }^{1 *}$, M. T. Dhikusooka ${ }^{1}$, S. N. Wekesa ${ }^{4,5}$, H. R.

6 Siegismund $^{6}$, V. B. Muwanika ${ }^{4}$ and K. Tjørnehøj ${ }^{3}$

7

$8{ }^{1}$ National Animal Disease Diagnostics and Epidemiology Centre, Ministry of Agriculture

9 Animal Industry and Fisheries, P. O. Box 513, Entebbe, Uganda

10

${ }^{2}$ Department of Biotechnical and Diagnostic Sciences, College of Veterinary Medicine, Animal

Resources and Biosecurity, Makerere University, P. O. Box 7062, Kampala, Uganda

${ }^{3}$ National Veterinary Institute, Technical University of Denmark, Lindholm, DK 4771, 15 Kalvehave, Denmark

${ }^{4}$ Department of Environmental Management, College of Agricultural and Environmental

Sciences, Makerere University, P. O. Box 7062, Kampala, Uganda

${ }^{5}$ Foot-and-Mouth Disease Laboratory, Ministry of Livestock Development, P. O. Box 18021, 21 Embakasi, Nairobi, Kenya

${ }^{6}$ Department of Biology, University of Copenhagen, Ole Maaløes Vej 5, DK-2200, Copenhagen, Denmark

\section{*Corresponding author}

27 Chrisostom Ayebazibwe

28 National Animal Disease Diagnostics and Epidemiology Centre,

29 Ministry of Agriculture Animal Industry and Fisheries,

30 P. O. Box 513, Entebbe, Uganda

31 Email address: cayebazibwe@gmail.com

32 Tel: +256772626215 


\section{Summary}

2 Control of foot-and-mouth disease (FMD) in Uganda by ring vaccination largely depends on

3 costly trivalent vaccines and use of monovalent vaccines could improve the cost effectiveness.

4 This, however, requires application of highly specific diagnostic tests. This study investigated

5 outbreaks of FMD in seven Ugandan districts, during 2011, using the PrioCHECK FMD-NS ${ }^{\circledR}$

6 ELISA, solid phase blocking ELISAs (SPBEs) and virus neutralization tests (VNTs), together

7 with virological analyses for characterization of the responsible viruses. Two hundred and

8 eighteen (218) cattle and 23 goat sera as well as 82 oropharyngeal fluid/epithelial tissue

9 samples, were collected. Some $50 \%$ of the cattle and $17 \%$ of the goat sera were positive by the

10 PrioCHECK FMD-NS ${ }^{\circledR}$ ELISA, while SPBEs identified titres $\geq 80$ for antibodies against

11 serotype O FMD virus (FMDV) in 51\% of the anti-NSP positive cattle sera. However, 35\% of

12 the anti-NSP positive cattle sera had SPBE titres $\geq 80$ against multiple serotypes, primarily

13 against serotypes O, SAT 1 and SAT 3.

14 Comparison of SPBEs and VNTs for the detection of antibodies against serotypes O, SAT 1

15 and SAT 3 in 72 NSP positive cattle sera showed comparable results against serotype $\mathrm{O}(\mathrm{P}=$

16 0.181), while VNTs detected significantly fewer samples positive for antibodies against SAT

171 and SAT 3 than the SPBEs $(P<0.001)$. Detection of antibodies against serotype $O$ was consistent with the isolation of serotype O FMDVs from 13 samples. Four of these viruses were sequenced and belonged to two distinct lineages within the East Africa-2 (EA-2) topotype, each differing from the currently used vaccine strain (EA-1 topotype). The relationships of these lineages to other serotype $\mathrm{O}$ viruses in the Eastern Africa region are discussed.

23 To enhance the control of FMD in Uganda, there is need to improve the specificity of the SAT-

24 SPBEs, perform vaccine matching and implement improved regional FMD control. 
1 Keywords: Foot-and-mouth disease, FMDV, serotypes, endemic, Uganda

\section{Introduction}

4 Foot-and-mouth disease (FMD) is a highly transmissible, acute vesicular disease of cloven-

5 hoofed animals including domesticated and wild ruminants and pigs (Alexandersen and 6 Mowat, 2005; Grubman and Baxt, 2004). The disease is endemic in Uganda and most FMD

7 outbreaks have been observed within cattle with severe effects on food security and household

8 income (Ayebazibwe et al., 2010a; Rutagwenda, 2003). FMD virus (FMDV) exists in seven

9 antigenically distinct serotypes (O, A, C, Asia 1, SAT 1, SAT 2 and SAT 3) with different 10 geographical distributions but causing clinically similar disease (Knowles and Samuel, 2003;

11 Rweyemamu et al., 2008). In Uganda, recent isolates of FMDV from cattle have mostly been serotype O (Balinda et al., 2010b; Kasambula et al., 2012) but SAT 2 was also detected

13 (Balinda et al., 2010a), while SAT 1 and SAT 2 viruses have been isolated from African

14 buffalos (Syncerus caffer) (Ayebazibwe et al., 2010c). SAT 3 virus was last isolated (within

15 Uganda) from African buffalos in Queen Elizabeth National Park (QENP) in 1997 (Kalema-

16 Zikusoka et al., 2005) while a serotype C strain was last identified in 1971 and Asia 1 has never

17 been diagnosed on the African continent (Vosloo et al., 2002).

18 Post-outbreak ring vaccination is one of the control strategies used within Uganda in the event 19 of an outbreak (Namatovu et al., 2013). However, since vaccination against one serotype does 20 not confer protection against other serotypes (Rweyemamu et al., 2008), there is a need for 21 accurate serotype identification, if effective vaccines are to be selected.

22 According to the OIE, detection of FMDV antigen or nucleic acid in epithelial and vesicular 23 fluids using virological or molecular techniques is sufficient for positive diagnosis (OIE, 2012), 24 since these tests are relatively sensitive, specific and can be quick (Callahan et al., 2002; Paixao 25 et al., 2008). However, the difficulties in obtaining appropriate virus-containing material and 
1 lack of the required biocontainment level and infrastructure has limited use of some of these

2 techniques in FMD endemic areas (Longjam et al., 2011; OIE, 2008 ; OIE, 2012; Paixao et al.,

3 2008). Consequently, like a number of other countries, Uganda still relies on serological tests

4 to serotype FMD outbreaks and for obtaining information for selection of vaccines (Muleme

5 et al., 2012), since these assays are inexpensive, suitable for screening many samples, not

6 dependent on cell cultures and only require low level biocontainment facilities (OIE, 2012).

7 Pan-FMDV antibody ELISAs based on FMDV non-structural proteins (NSPs) have been

8 developed and used for screening herds for the presence of antibodies against NSPs which are

9 elicited during FMDV infection (Clavijo et al., 2004; Sorensen et al., 2005). However, these

10 tests do not identify the serotype-specificity of the antibodies, which has to be determined using

11 separate antibody tests for each of the seven serotypes of FMDV. Such assays include the OIE recommended liquid phase blocking ELISA (LPBE) and virus neutralization test (VNT) (OIE, 2012) but also the solid phase blocking ELISA (SPBE) (Balinda et al., 2009; Have and Jensen, 1983). All three tests detect antibodies against the viral structural proteins which are elicited by both vaccination and infection (OIE, 2012). The SPBE has been successfully used in

16 Denmark, which is free from FMD, and was recently implemented on sera from Ugandan buffalos and livestock (Ayebazibwe et al., 2010b; Balinda et al., 2009; Mwiine et al., 2010b). However, the performance of the SPBE in the endemic situation has never been compared to the virus neutralization test (VNT), the OIE "gold standard”, for detection of antibodies against

\section{FMDV.}

21 The aim of this study was to evaluate the performance of the SPBEs for the identification of 22 the serotype-specificity of antibodies generated against FMDV in an endemic situation which has repeated outbreaks and where vaccination is used. Moreover, these assays were applied in conjunction with other serological and virological assays to characterize the viruses responsible for the Ugandan FMD outbreaks in 2011. 


\section{Materials and methods}

\section{Study area and sampling strategy}

4 This study was conducted on outbreak samples collected from seven Ugandan districts that

5 reported FMD outbreaks between January and April, 2011. These included: Bukedea and Kumi

6 in Eastern region, Gomba and Sembabule in Central region, Kiruhura and Isingiro in South-

7 Western region and Rakai in Southern region (Figure 1). With the exception of farms in Gomba

8 and Sembabule, which were fenced, the sampled herds were reared under free-range communal

9 grazing management systems with some herds in the Southern region grazing with cattle close

10 to, or across, the border with Tanzania.

11 The districts were purposively selected based on reported FMD outbreaks and the in-charge veterinary officer offered guidance about the affected herds. Samples were collected mainly from cattle herds (local breeds) which showed overt clinical signs but, when present, also from

14 a few apparently healthy goats grazing with the affected cattle. Bukedea, Gomba and Kumi

15 districts had not vaccinated against FMDV for at least 10 years and the herd Kr.1 from Kiruhura

16 district had not vaccinated for 3 years, while the vaccination status was unknown for Rakai and

17 Sembabule. In contrast, Isingiro district had vaccinated within the 8 months before the sampling (Table 2). Additionally, samples were taken from one healthy Friesian cross-breed herd (Kr.2) in Kiruhura district that had last experienced an outbreak of FMD in 1991 but had vaccinated their animals shortly before the sampling. When vaccination had been performed, 21 a trivalent, non-purified vaccine including FMDV serotypes O, SAT 1 and SAT 2 had been used.

\section{Sampling and sample preparation}

24 The animals were clinically examined for oral and hoof lesions, with consent of the farmers, and samples were collected including blood, oral epithelial tissues and oro-pharyngeal fluids 
1 (OPs) from affected cattle, while blood was collected from goats. Altogether, 218 blood, 2

2 tissue and 80 OP samples were collected from cattle, and 23 blood samples were collected from

3 goats. In Gomba, only blood samples were obtained.

4 Farmers were interviewed about the age of their animals, animal management system,

5 suspected source of outbreak, previous outbreaks and vaccination including, if applicable, the

6 type of vaccine used. In addition, the in-charge veterinary officers were interviewed about the

7 history of outbreaks and vaccination, the vaccine used and the instituted control measures.

8 Sera were prepared from blood samples in the field using a Mobilespin 12V field centrifuge

9 (Mobilespin, Vulcon Technologies, Gransview, MO, USA) and kept on ice until stored at

$10-20^{\circ} \mathrm{C}$ in the laboratory. The OP fluids were preserved in phosphate-buffered saline (PBS)

11 while epithelial tissues were preserved using 50\% PBS and 50\% glycerol, and both were stored

12 in liquid nitrogen during transit to the laboratory where they were stored at $-80^{\circ} \mathrm{C}$.

13 Laboratory methods

14 Screening for antibodies against FMDV non-structural proteins (NSPs)

15 Sera were screened for antibodies against NSPs using the PrioCHECK ${ }^{\circledR}$ FMDV NS kit

16 (Prionics ${ }^{\circledR}$ AG, Zurich, Switzerland), as developed by Sorensen et al. (1998), according to the

17 manufacturer's instructions except that optical density (OD) values were measured at dual wavelengths of $450 \mathrm{~nm}$ and $620 \mathrm{~nm}$ using a Multiskan Ascent spectrophotometer (Thermo Labsystems Oy, Helsinki, Finland). Results were expressed as percentage inhibition (PI) relative to the mean of the negative controls; $\mathrm{PI}=100-\left(\left(\mathrm{OD}\right.\right.$ of test sample $\left(\mathrm{OD}_{450}-\mathrm{OD}_{620}\right) / \mathrm{OD}$ of mean negative control $\left.\left.\left(\mathrm{OD}_{450}-\mathrm{OD}_{620}\right)\right) \times 100\right)$. Sera with $\mathrm{PI} \geq 50 \%$ were considered positive.

Determination of serotype-specificity of antibodies against FMDV using SPBEs Serotypespecific antibodies, in the samples positive in the Priocheck ${ }^{\circledR}$ FMDV NS test, were detected using serotype-specific SPBEs as described by Balinda et al. (2009). Samples were screened at a dilution of 1:10 in each of the seven SPBEs. The optical density (OD) values were 
1 measured as described for the PrioCHECK ${ }^{\circledR}$ FMDV NS test and ODs were converted into

2 optical density percentage (ODP) values using the formula; ODP = (OD of test sample (OD 450

$\left.3-\mathrm{OD}_{620}\right) / \mathrm{OD}$ of mean negative control $\left.\left(\mathrm{OD}_{450}-\mathrm{OD}_{620}\right)\right) \times 100$. The samples were considered

4 positive when the ODP values were $\leq 50 \%$ for serotypes O, SAT 1 , SAT 2 and SAT $3, \leq 45 \%$

5 for serotype A and $\leq 35 \%$ for serotypes C and Asia 1 (Balinda et al., 2009).

6 All positive sera were titrated using two-fold dilutions from 1:10 to 1:1280 in the relevant

7 SPBEs and titres were expressed as the reciprocal of the highest positive dilution. In this study,

8 the cut-off was set at a titre $\geq 80$ being positive for all serotypes.

9 Detection of serotype-specific antibodies against FMDV using VNT

10 The few samples with titres $\geq 80$ in the SPBEs for antibodies against A, C, Asia 1 and SAT 2

11 were tested in VNT. In addition, the 72 samples positive in the NSP-ELISA that were available

12 in adequate amounts were analysed using the VNT for antibodies against O, SAT 1 and SAT

133 to compare with the SPBE results. The protocol was adapted from the procedure described

14 in the OIE terrestrial manual (OIE, 2012). Briefly, on the test plate, sera were two-fold diluted

15 in quadruplicate from 1:10 to 1:1280. Virus strains used were: O Manisa, A Iraq 24/64, C

16 Noville, Asia 1 IND 8/79, SAT 1 BOT/68, SAT 2 ZIM 5/81 and SAT 3 ZIM 4/81. Controls

17 included cell control, 10 -fold titration of the virus $\left(10^{-3}-10^{0}\right)$ and titration of a positive standard

18 serum. To all wells, except for the cell controls and virus control, 100 TCID 50 of FMDV (in

$1950 \mu \mathrm{l})$ was added to an equal volume of diluted serum and incubated at $37^{\circ} \mathrm{C}$ for 1 hour,

20 followed by addition of $50 \mu \mathrm{l}$ of swine kidney (SK) cell suspension (200,000 cells/ml $+20 \%$

21 FCS) to all wells, and subsequent incubation at $37^{\circ} \mathrm{C}$ for 3 days. The plate wells were read for

22 cytopathic effect (CPE) under the microscope and 50\% end-point titres calculated according to

23 Reed and Muench, (1938). A titre $\geq 45$ was considered positive, while 16-44 was considered

24 doubtful and $<16$ negative.

25 Detection of FMDV by virus isolation (VI) 
1 The preparation of epithelial tissues and procedure for virus isolation were adapted from the

2 method described in the OIE terrestrial manual (OIE, 2012) essentially as in Ayebazibwe et al.

3 (2010c). Briefly, the samples (OPs or 10\% suspension of epithelial tissues in Eagles media)

4 were diluted 1:2 and 1:4, and each dilution was added to 5 wells of 96 well tissue culture plates

5 with monolayers of primary bovine thyroid (BTY) cells. Test samples were separated by wells

6 with uninfected cells that served as negative control and the plates were incubated for two hours

7 at $37^{\circ} \mathrm{C}$ (with $\mathrm{CO}_{2}$ ). Thereafter all wells containing samples were washed using Eagles media

8 with $2 \%$ FCS and $150 \mu \mathrm{l} /$ well of the same media was added and further incubated for 1-2 days

9 as above. The plates were examined for CPE every 24 hours and CPE-positive samples were

10 frozen for harvesting, while those without CPE after 48 hours were harvested by freeze-

11 thawing and subjected to another passage on BTY monolayers as described above. Samples which showed no CPE following two passages were considered negative.

Verification of FMDV in CPE-positive samples and identification of FMDV serotype by antigen ELISA (Ag ELISA)

The presence of FMDV in CPE-positive harvests was investigated using an in-house serotypespecific antigen ELISA based on the description by OIE (2012) as described by Ayebazibwe et al. (2010c). Briefly, the same reagents as in the SPBE were used, but the rabbit hyperimmune sera for all seven serotypes were each coated in one row of the same plate and the samples were then added in duplicate to all seven rows. Moreover, the serotype-specific positive controls (strong and weak) and negative cell culture controls were added in single wells in the relevant rows. Positive reactions were identified using the serotype-specific guinea pig antisera and results were interpreted after subtracting the OD-value of the negative control wells from that of the samples. Any sample with an OD-difference of $>0.2$ was considered positive, while values between 0.1 and 0.2 were inconclusive. 
1 RNA was extracted from CPE positive cell culture supernatant using the Viral RNA Mini Spin

2 Protocol in the QIAamp ${ }^{\circledR}$ Viral RNA Mini Kit (Qiagen, GmbH, Hamburg, Germany) following

3 the manufacturer's instruction. cDNA for the qRT-PCR was synthesized using the TaqMan kit

4 (Perkin Elmer (PE) Biosystems) by adding $9 \mu$ l of Master mix $(1.5 \mu l$ of $10 \times$ TaqMan RT-

5 buffer, $3.3 \mu \mathrm{l}$ of $25 \mathrm{mM} \mathrm{MgCl}_{2}, 3.0 \mu \mathrm{l}$ of dNTP (2.5mM each)), $0.5 \mu \mathrm{l}$ of $50 \mu \mathrm{M}$ Random

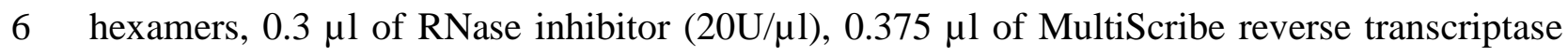

$7 \quad(100 \mathrm{U} / \mu \mathrm{l}$ Moloney RT) and $6 \mu \mathrm{l}$ of RNA per tube. The tubes were transferred to a heating

8 block and incubated at $48^{\circ} \mathrm{C}$ for $45 \mathrm{~min}$ followed by $95^{\circ} \mathrm{C}$ for $5 \mathrm{~min}$. The qRT-PCR was

9 performed using primers and probes as described previously (Reid et al., 2002).

10 Sequencing of FMDV VP1 coding region

11 The cDNA for sequencing was synthesized using Ready-To-GoTM You-Prime First-strand

12 Beads (GE Healthcare Life Sciences, Uppsala, Sweden) using pdN6 Random

13 Hexamers $(50 \mathrm{ng} / \mu \mathrm{l})$. The PCR products corresponding to the VP1-coding region for

14 sequencing were prepared as described in Balinda et al. (2010b) using reactions of $50 \mu 1$ volume

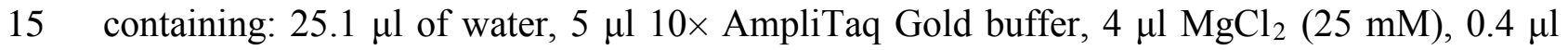
dNTPs (2.5 mM each), $0.5 \mu$ of Amplitaq Gold® DNA polymerase (Applied Biosystems, Life Technologies ), $5 \mu \mathrm{l}$ of template cDNA and $5 \mu \mathrm{l}$ of the forward (11-FPN 29: 5'-3' GCIGCIGACTACGCITACACYGC, where $\mathrm{I}=$ inosine and $\mathrm{Y}=\mathrm{C}$ or $\mathrm{T})$ and reverse (11-FPN 28: 5'-3' GGGCCCAGGGTTGGACTC) primers, both at a concentration of $5 \mathrm{pmol} / \mu \mathrm{l}$ as used by Wekesa et al. (2013).

The PCR products were analysed on gels using $1.5 \%$ Seakem GTG agarose in 1 X TAE (low EDTA) buffer with a marker (ФX 174 HaeIII digest) (Fisher Scientific, Slangerup, Denmark). Electrophoresis was performed using 120 volts for 1 hour and the gel was stained in 250 mls of water containing $40 \mu \mathrm{l}$ of $1 \% \mathrm{w} / \mathrm{v}$ ethidium bromide for 30 minutes on a shaking table. Gel purification of the amplicons was performed using the Qiaquick ${ }^{\circledR}$ gel extraction kit (Qiagen, 
1 GmbH, Hamburg, Germany) and Cycle sequencing was performed with 1-50 ng of PCR

2 product using the Big dye ${ }^{\circledR}$ terminator v3.1 cycle sequencing kit (Applied Biosystems) and an

3 ABI PRISM ${ }^{\circledR} 3700$ automated DNA sequencer (Applied Biosystems).

\section{Data analysis}

5 The differences between the seroprevalence values obtained with SPBEs and VNT for

6 antibodies against serotypes O, SAT 1 and SAT 3 were analysed using the McNemar test

7 (Motulsky, 1995).

8 Base calling of nucleotide sequences was done using seqMan Pro software (DNAstar, Inc.,

9 Madison, USA). Sequences from older East African isolates which are related to the study 10 sequences were obtained using BLAST searches from NCBI (http://www.ncbi.nlm.nih.gov/).

11 The sequences analysed correspond to the VP1 coding region and details of the new and related sequences are summarised in Table 1. Multiple sequences were aligned using Muscle (codons)

13 (Edgar, 2004) incorporated in MEGA 5 (Tamura et al., 2011). A phylogenetic tree of these 14 sequences was estimated using the Neighbor-Joining method (Saitou and Nei, 1987). The 15 percentage of replicate trees in which the associated taxa clustered together in the bootstrap 16 test (2000 replicates) is shown next to the branches (Felsenstein, 1985). The tree is drawn to 17 scale with branch lengths in the same units as those of the evolutionary distances used to infer 18 the phylogenetic tree. The evolutionary distances were computed using the Tamura 319 parameter method (Tamura, 1992) and are in the units of the number of base substitutions per 20 site. The rate variation among sites was modeled with a gamma distribution (shape parameter $21=1$ ). The analysis involved 18 nucleotide sequences and codon positions included were $221^{\text {st }}+2^{\text {nd }}+3^{\text {rd }}$. All positions containing gaps and missing data were eliminated. There were a total 23 of 636 positions in the final dataset. Evolutionary analyses were conducted in MEGA 5 24 (Tamura et al., 2011).

\section{Ethical approval}


1 This research is part of a larger on-going strategic project 'Transboundary Animal Diseases in

2 East Africa'. Ethical approval for the project was kindly granted by the Ministry of Agriculture

3 Animal Industry and Fisheries, Uganda.

5 Results

6 Screening for antibodies against FMDV using PrioCHECK ${ }^{\circledR}$ FMDV NS ELISA

7 One hundred and nine out of 218 (50\%) cattle sera and four out of 23 (17\%) goat sera collected

8 from premises with suspected FMD had antibodies against NSPs with herd prevalences ranging

9 from $13 \%$ to $100 \%$ in cattle and from $0 \%$ to $33 \%$ in goats (Table 2).

10 Serotyping of antibodies against FMDV using SPBEs

11 All samples positive in the PrioCHECK ${ }^{\circledR}$ FMDV NS assay were screened in the seven SPBEs and positive sera were titrated when possible, however, due to insufficient amounts of serum, titration could not be carried out for a few positive samples (4-12 samples depending on the SPBE) (Table 2). After titration in SPBEs, serotype-specific antibody titres $\geq 80$ against serotypes O, A, C, Asia 1, SAT 1, SAT 2 and SAT 3 were identified in 51\%, 7\%, 3\%, 1\%, $38 \%, 10 \%$ and $24 \%$, respectively, of the $97-105$ sera that could be tested in the respective SPBEs (Table 2). Forty four of the 107 anti-NSP positive samples run on SPBEs (41\%) did not have antibody titres $\geq 80$ in any of the SPBEs, while high antibody titres against a single serotype were found in 25 (23\%) and against more than one serotype in 38 (36\%) of the samples. The majority of the samples positive for only one serotype had antibodies against serotype O (19/25), while others had antibodies against serotypes A (2), SAT 1 (3) and SAT 3 (1) (data not shown). The 38 samples with high titres against more than one serotype came from infected herds in all districts and were more frequent in districts with higher seroprevalences for antibodies against NSP, but also from the vaccinated, non-infected herd Kr.2 (Table 2). The majority (30) had antibodies against serotype $\mathrm{O}$ in combination with 
1 antibodies against SAT 1 only (13), against SAT 1/other serotypes (13) or against SAT

2 3/other serotypes (4) (data not shown). In 23 of these 30 samples, titres against serotype O

3 were higher than or equal to titres against other serotypes, while titres against SAT 1 were

4 highest in the remaining seven sera (data not shown). Eight samples only had high titres

5 against the SAT serotypes, either against SAT 1 and SAT 3 (6) or against SAT 1 and SAT 2

6 (2).

7 In goats, evidence of exposure to FMDV as determined by SPBE was only found in one goat

8 from Gomba that had an antibody titre of 1280 against $\mathrm{O}$ and 160 against SAT 1 (Table 2).

\section{Determination of serotype-specific antibodies using VNT}

10 For the sera containing antibodies against SAT 2, eight of the ten samples with titres $\geq 80$ in 11 SPBE were analysed in the VNT, and six of these were confirmed positive; two of the positive samples came from the uninfected but vaccinated herd (Kr.2) with SAT 2 neutralizing antibody titres of 57 and 80 in combination with low and high neutralizing titres against SAT 1 or O, respectively. The remaining four sera came from one farm in Rakai and had titres ranging from 57 to 160 against SAT 2, but with higher or comparable neutralizing titres against serotype O. Moreover, SPBE antibody titres $\geq 80$ against serotypes A, C and Asia 1 in seven, three and one sera, respectively, were not confirmed in VNT (data not shown). The comparison of the test performance for SPBEs and VNT for serotypes O, SAT 1 and SAT 3 on 72/109 (66\%) anti-NSP positive samples is summarized in Table 3 . Thirty nine of the 72 samples (54\%) showed evidence of antibodies against $\mathrm{O}$ by both tests, while for each of SAT

211 and SAT 3 only one sample (1.4\%) was positive in both assays. The sample positive by VNT for antibodies against SAT 1 also had neutralizing antibodies against O but with a higher titre against SAT 1 (538 and 190, respectively) and was from the recently vaccinated herd (Kr.2), while the single serum positive for antibodies against SAT 3 had a higher titre against O (64 and 226, respectively) and was from Kumi district which last vaccinated their animals more 
1 than 10 years back. The VNT detected slightly more samples positive (49/72) for antibodies

2 against serotype $\mathrm{O}$ as compared to the SPBE-O (43/72) but the difference was not statistically

3 significant $(P=0.181)$. In contrast, the VNT test detected significantly fewer samples positive

4 for antibodies against serotypes SAT 1 (1/72) and SAT 3 (1/72) as compared to SPBE for SAT

$51(33 / 72)$ and SAT $3(22 / 72)(P<0.001$ for both).

\section{Virus characterization by VI, Ag ELISA, RT-PCR and Sequencing}

7 Nineteen OPs out of the 82 OP/epithelial tissue samples used for virus isolation (23\%)

8 produced CPE directly in primary BTY cells or after the second passage; these were from

9 Bukedea (one), Kumi (eight), Rakai (one) and Sembabule (nine) districts. None of the samples

10 from Isingiro (15/82) and Kiruhura (19/82) were positive by VI (data not shown). Thirteen out

11 of the 19 CPE containing cell culture harvests were positive on Ag ELISA and were identified

12 as serotype O; moreover, nine of these were also positive with lower ODs in SAT 3 Ag ELISA

13 (data not shown).

14 Using qRT-PCR assays, nine of the 19 CPE containing cell culture harvests had Ct-values <

1527 , one of the selection criteria for samples for sequencing. The four samples selected for

16 sequencing had $\mathrm{Ct}$ values within the range of 17 to 27 , were positive for serotype $\mathrm{O}$ and SAT

173 using Ag ELISA although with greater ODs for O than SAT 3, and these included an isolate

18 from each of the four districts Bukedea, Kumi, Rakai and Sembabule. Testing the selected

19 samples by conventional PCR, using two primer sets designed to target primarily either the

20 SAT-serotypes of FMDV or serotypes O, A, C and Asia 1 of FMDV, yielded products only

21 with the latter. The VP1 coding sequences (639 nt length) were determined and when compared

22 with other sequences from NCBI, Genbank, using Blast, each of them were most closely

23 matched with serotype O FMDVs (Table 1), thus confirming that serotype O was responsible

24 for the outbreaks in these districts. 
1 Assessment of phylogenetic relationships with older, topotype-defined, serotype $\mathrm{O}$ isolates

2 from East Africa (Table 1) showed that all four strains were grouped with known strains

3 belonging to the topotype EA-2 (Figure 2). The predicted amino acid sequences for the VP1s

4 derived from the nucleotide sequences are shown in Figure 3. The sequences of the virus

5 isolates U07/11and U24/11 from Rakai and Sembabule, respectively, were closely related to

6 each other (pairwise amino acid identity of 99\% and nucleotide identity of 99.5\%), while the

7 isolates U04/11 and U19/11 from Bukedea and Kumi, respectively, were identical within the

8 VP1 coding sequence. However, the two sets of sequences from Eastern (Bukedea and Kumi)

9 and Southern (Rakai and Sembabule) Uganda were quite distinct from each other (pairwise

10 amino acid identity of 93\%) with 71/639 (11\%) nucleotide differences. Hence, these viruses

11 belong to two different lineages within the EA-2 topotype based on a cut off of $>7.5 \%$ nucleotide difference for separating lineages and $<15 \%$ difference among topotypes in the VP1 coding region of FMDV RNA (Samuel and Knowles, 2001; Vosloo et al., 1992). The U04/11 and U19/11 viruses were each very closely related to a FMDV isolate (K251/2010) from Kwanza, Western Kenya (Wekesa et al., 2013) with nucleotide identity of 634/639 (99\%), while both the U07/11 and U24/11 isolates were closely related to the U18/06 virus from Mpigi district, Uganda with nucleotide identities of $96 \%$.

One hundred and thirty six (21\%) variable sites between the 2011 outbreak sequences and the vaccine strain in use $(\mathrm{O} / \mathrm{K} 77 / 78$, which is topotype EA-1), were determined across the 639 nucleotides which encode substitutions of 27/213 amino acids (13\%). The U07/11 and U24/11 viruses had pairwise amino acid identity of $90 \%$ (83\% nucleotide identity) with the vaccine strain while the U04/11 and U19/11 viruses each had pairwise amino acid identity of $92 \%$ (84\% nucleotide identity) with the vaccine strain. Similarly, the K251/2010 isolate (Wekesa et al., 2013) had pairwise amino acid identity of $91 \%$ (84\% nucleotide identity) with the vaccine strain. 
1 Pairwise comparison of the 2011 outbreak sequences with the vaccine strain showed 18 (8.5\%)

2 amino acid variations in the U04/11 and U19/11 viruses and 23 amino acid variations (10.8\%)

3 in the U07/11 and U24/11 isolates. Most amino acid variations were noted between amino acid

4 residues 133 to 141 which is part of the GH-loop and a key antigenic site (Aggarwal and

5 Barnett, 2002 ). However, the RGD motif (residues 145-147) within these viruses was

6 conserved and so was the flanking region of the RGD motif as far as the -3 position.

7 Conservation was also observed as far as +4 in all the viruses except for the U07/11 sequence

8 with Alanine (A) instead of Valine (V) at +3 (amino acid residue 150) which is adjacent to

9 residue 149, a critical component of antigenic site 5 (Crowther et al., 1993) within VP1. In the

$10 \mathrm{U} 24 / 11$ sequence, there was also variation from Alanine (A) to Valine (V) at residue 152 which

11 is close to 154, a critical residue within antigenic site 1 within VP1 (Kitson et al., 1990). In

12 addition, Threonine (T) was replaced by Glutamine (Q) within the U04/11 and U19/11 viruses

13 at residue 43, which is a critical residue within antigenic site 3 (Figure 3).

15 Discussion

16 The presence of antibodies against FMDV NSPs in cattle sera collected from herds with clinical signs of FMD strongly supported the clinical diagnosis. Moreover, the 60-90\% prevalence of antibodies against FMDV NSPs in unvaccinated herds from Bukedea, Isingiro, Kumi and Rakai districts indicates that the sampling took place after considerable spread of the infection within the herds, while the lower seroprevalence consistently observed in herds from Gomba (29\%) and Sembabule (24\%) districts, as well as in the non-vaccinated herd in Kiruhura (45\%), accords with sampling in an earlier phase of the outbreak (Sorensen et al., 1998). The very high prevalence of anti-NSP antibodies in herd Kr.2 in Kiruhura district, which last had an outbreak in 1991 but where the cattle are vaccinated on a yearly basis, may be attributed to repeated use of non-purified vaccines (Ayebazibwe et al., 2012; Sutmoller et al., 2003). 
1 The seroprevalences of antibodies against FMDV NSPs found in this study are comparable to

2 the levels found in Southern Ugandan cattle in a 2006 post FMD outbreak sampling (Mwiine

3 et al., 2010b). In goats, the overall prevalence for antibodies against FMDV was 17\%, which

4 is lower than reported from a 2006 post outbreak sampling in Kasese and Mbarara districts, but

5 comparable to a 2007 random sampling of goats in Kasese district (Balinda et al., 2009).

6 The serological investigations into the FMDV serotype involved in the outbreaks using SPBEs

7 gave a complex picture since $36 \%$ of the samples had antibody titres above the cut off level for

8 more than one serotype, however, antibody titres were generally higher against O and SAT 1,

9 followed by SAT 3, while titres against serotypes A, C, Asia 1 and SAT 2 were equal to or

10 lower than at least one other serotype in all samples. Thus, based on the SPBEs, it was difficult

11 to conclude whether serotype O or SAT 1 was responsible for the outbreak, however, the VNTs gave a much simpler picture since they predominantly identified neutralizing antibodies against serotype O. Furthermore, only serotype O FMDVs were isolated from OP fluids collected in some of the districts involved in the 2011 outbreaks which confirmed that the outbreaks were caused by serotype O FMDV.

16 In herd Kr.2 that had been vaccinated shortly before sampling, the high simultaneous antibody titres against serotypes O, SAT 1 and SAT 2 are probably due to vaccination with the trivalent vaccines (O, SAT 1 and SAT 2) that are used in Uganda.

The absence of serotype-specific neutralizing antibodies (as determined by VNT) in the few samples which were positive in SPBEs for antibodies against serotypes A, C and Asia 1, and in the vast majority of samples positive in the SAT 1 and SAT 3 SPBEs point to cross reactions between serotypes, which are not uncommon with SPBEs (Ayebazibwe et al., 2010b; Ayebazibwe et al., 2010c; Balinda et al., 2009; Mwiine et al., 2010a; Mwiine et al., 2010b; Mwiine et al., 2010c) and the OIE recommended antibody ELISAs (Hamblin et al., 1986a; 
1 al., 1986a; Hedger et al., 1982). According to Hamblin et al. (1986a), these cross-reactions are

2 likely a reflection of some antigenic relationship between these virus serotypes, however, for

3 regularly vaccinated herds, they could also be due to repeated vaccination which complicates

4 the serological picture in endemic situations (Mwiine et al., 2010a). Moreover, the higher levels

5 of antibodies against serotypes other than $\mathrm{O}$, as found in a few samples in the SPBEs, could

6 also be due to heterotypic responses to the causative virus caused by priming effects from past

7 exposures (Hedger et al., 1982).

8 The specificity performance of the SAT serotype SPBEs seemed particularly poor in this study.

9 Since it has been previously shown that the antibody response measured by SPBE is very 10 diverse in both vaccinated and unvaccinated infected animals for 2-3 weeks after infection

11 (Tjørnehøj, K., unpublished data), it is expected that the SPBEs may perform better if used later than 4 weeks after infection as was observed in a post outbreak study of the Ugandan 2006

13 FMD outbreaks (Mwiine et al., 2010b).

14 With regard to antibodies against SAT 3, the relatively large number of samples that were 15 positive in the SAT 3 SPBE but negative in the corresponding VNT is of particular concern, 16 because this serotype has only been isolated from Ugandan buffalos in 1997 (Kalema-Zikusoka et al., 2005) and has never been isolated from Ugandan cattle, moreover, this serotype is not part of the employed vaccines. Thus, our results support the suspicion that the anti-SAT 3 SPBE is very unspecific and gives strong cross-reactions with antibodies against other FMDV serotypes (Tjørnehøj, K., unpublished data).

21 To avoid the diagnostic issues of cross reactivity due to repeated vaccination, Balinda et al. 22 (2009) and Mwiine et al. (2010a) recommended use of samples from unvaccinated species, like small ruminants, indeed, in the current study a single goat had high antibody titres against serotype $\mathrm{O}$ and had a lower titre towards SAT 1 , which accords with the findings in cattle in these outbreaks. 
1 The Ag ELISA identified 13 culture harvests from OPs collected from districts of Bukedea,

2 Kumi, Sembabule and Rakai positive for serotype $O$ virus and indeed serotype O FMDV

3 isolates were confirmed by sequencing four of these samples (one selected per district)

4 indicating the presence of either acute or persistent infection. The VP1 coding regions of these

5 four isolates showed that all of these viruses belonged to the same EA-2 topotype which is well

6 established in Uganda (Ayelet et al., 2009; Balinda et al., 2010b; Kasambula et al., 2012).

7 Bukedea and Kumi districts are situated next to each other in the Eastern region of Uganda,

8 while Rakai and Sembabule are neighbouring districts in the Southern region, and not

9 surprisingly, this was reflected in the genetic clusters with pairwise amino acid identities of

10 100\% (Bukedea and Kumi) and 99\% (Rakai and Sembabule), which indicates local inter-

11 district livestock transmission which could be due to belated reporting of FMD outbreaks or to

12 ineffective implementation of quarantine. The $<5 \%$ nucleotide difference in the viruses from

13 the Southern region indicates that they belong to the same lineage, as did the viruses from

14 Eastern Uganda and Western Kenya, while the extent of nucleotide difference between the two

15 pairs of Ugandan viruses (11\%) showed that these were two different lineages (Samuel and

16 Knowles, 2001; Vosloo et al., 1992), which implies circulation of more than one serotype O

17 FMDV lineage during the 2011 outbreaks. The occurrence of related viruses in Eastern

18 (Bukedea and Kumi) Uganda and in Western Kenya (99\% nucleotide identity) provides further

19 evidence for transboundary mobility of FMDV which may be attributed to uncontrolled cross

20 border movements as suggested previously by Balinda et al., (2010b).

21 The serotype $\mathrm{O}$ vaccine strain incorporated in the trivalent vaccines used in Uganda belongs to

22 topotype EA-1 and it is not surprising that nucleotide difference of $16-17 \%$ and a number of

23 amino acid substitutions separate the identified EA-2 topotype viruses from the vaccine strain.

24 Some of these changes occur at critical antigenic sites (Figure 3) highlighting a need for vaccine 
1 matching studies to establish the level of protection conferred by the current vaccine against

2 the currently circulating virus strains.

3 In conclusion, the presence of antibodies against FMDV NSPs in samples from unvaccinated 4 herds with recent disease confirmed FMDV infection. Further serological investigations, using 5 SPBEs and VNTs, identified antibodies against serotype O, however, there were a conspicuous 6 number of cross-reactions in the SPBEs for antibodies against serotypes SAT 1 and SAT 3.

7 These results accorded with the isolation of four serotype O FMDVs, which, in contrast to the

8 topotype EA-1 vaccine strain, all belonged to topotype EA-2. The Ugandan isolates grouped 9 into a Southern Ugandan lineage and an Eastern Ugandan lineage, of which the latter was 10 closely related to a Western Kenyan isolate. The findings of this study highlight the challenges 11 involved in the diagnosis and control of FMD in endemic areas and emphasize the need to: (i) 12 improve the serotype-specificity of the existing SAT-SPBEs if they are to be used to give useful 13 information for cost effective vaccine selection, (ii) perform vaccine matching to establish the 14 level of protection conferred by existing vaccines against the currently circulating strains and 15 (iii) implement regional FMD control measures.

\section{Acknowledgements}

17 The study was funded by Danish International Development Agency (DANIDA) through the Transboundary Animal Diseases of East Africa Project (TADEA) (Project number: 10-006KU) and the authors declare no competing interests. Special thanks are due to: Eugene Arinaitwe,

20 Simon Peter Ruhweza and David Imunyoi at National Animal Disease Diagnostics and 21 Epidemiology Centre (NADDEC) for their assistance during sample collection; Jani 22 Christiansen, Jane Borch, Inge Nielsen, Tina Rasmussen and Preben Normann at Danish 23 Technical University (DTU), National Veterinary institute (Lindholm) for their technical assistance and Mr. Bernard Mwesigwa of FAO Uganda for assistance with drawing the map. 


\section{Author contributions}

2 AN and CA conceived and designed the study and together with MTD conducted the field work

3 and collected the samples. AN, MTD and SNW did laboratory analyses and AN also performed

4 data analyses and manuscript preparation. KT supervised the laboratory and immunological

5 data analyses while GJB, HRS and VBM supervised molecular data collection and analysis.

6 MTD and SNW also participated in proof reading and manuscript review while KT, GJB, CA,

7 VBM and HRS critically revised the manuscript. All authors read and approved the final

8 manuscript.

\section{References}

Aggarwal, N., and P.V. Barnett, 2002: Antigenic sites of foot-and-mouth disease virus (FMDV): analysis of the specificities of anti-FMDV antibodies after vaccination of naturally susceptible host species. J. Gen. Virol. 83, 775-782.

Alexandersen, S., and N. Mowat, 2005: Foot-and-mouth disease: host range and pathogenesis. Curr. Top. Microbiol. Immunol. 288, 9-42.

Ayebazibwe, C., F.N. Mwiine, S.N. Balinda, K. Tjornehoj, and S. Alexandersen, 2012: Application of the Ceditest ${ }^{\circledR}$ FMDV type $\mathrm{O}$ and FMDV NS enzyme-linked immunosorbent assays for detection of antibodies against foot-and-mouth disease virus in selected livestock and wildlife species in Uganda. J. Vet. Diagn. Invest. 24, 270-276.

Ayebazibwe, C., K. Tjornehoj, F.N. Mwiine, V.B. Muwanika, A.R. Okurut, H.R. Siegismund, and S. Alexandersen, 2010a: Patterns, risk factors and characteristics of reported and perceived foot-and-mouth disease (FMD) in Uganda. Trop. Anim. Health Prod. 42, 1547-1559.

Ayebazibwe, C., F.N. Mwiine, S.N. Balinda, K. Tjornehoj, C. Masembe, V.B. Muwanika, A.R. Okurut, H.R. Siegismund, and S. Alexandersen, 2010b: Antibodies against foot-and- 
mouth disease (FMD) virus in African buffalos (Syncerus caffer) in selected National Parks in Uganda (2001-2003). Transbound. Emerg. Dis. 57, 286-292.

Ayebazibwe, C., F.N. Mwiine, K. Tjørnehøj, S.N. Balinda, V.B. Muwanika, A.R. Ademun Okurut, G.J. Belsham, P. Normann, H.R. Siegismund, and S. Alexandersen, 2010c: The role of African buffalos (Syncerus caffer) in the maintenance of foot-and-mouth disease in Uganda. BMC Vet. Res. 6, 1-13.

Ayelet, G., M. Mahapatra, E. Gelaye, B.G. Egziabher, T. Rufeal, M. Sahle, N.P. Ferris, J. Wadsworth, G.H. Hutchings, and N.J. Knowles, 2009: Genetic characterization of footand-mouth disease viruses, Ethiopia, 1981-2007. Emerg. Infect. Dis. 15, 1409-1417.

Balinda, S.N., G.J. Belsham, C. Masembe, A.K. Sangula, H.R. Siegismund, and V.B. Muwanika, 2010a: Molecular characterization of SAT 2 foot-and-mouth disease virus from post-outbreak slaughtered animals: implications for disease control in Uganda. Epidemiol. Infect. 138, 1204-1210.

Balinda, S.N., A.K. Sangula, R. Heller, V.B. Muwanika, G.J. Belsham, C. Masembe, and H.R. Siegismund, 2010b: Diversity and transboundary mobility of serotype O foot-andmouth disease virus in East Africa: implications for vaccination policies. Infect Genet. Evol. 10, 1058-1065.

Balinda, S.N., K. Tjornehoj, V.B. Muwanika, A.K. Sangula, F.N. Mwiine, C. Ayebazibwe, C. Masembe, H.R. Siegismund, and S. Alexandersen, 2009: Prevalence estimates of antibodies towards foot-and-mouth disease virus in small ruminants in Uganda. Transbound. Emerg. Dis. 56, 362-371.

Callahan, J.D., F. Brown, F.A. Osorio, J.H. Sur, E. Kramer, G.W. Long, J. Lubroth, S.J. Ellis, K.S. Shoulars, K.L. Gaffney, D.L. Rock, and W.M. Nelson, 2002: Use of a portable real-time reverse transcriptase-polymerase chain reaction assay for rapid detection of foot-and-mouth disease virus. J. Am. Vet. Med. Assoc. 220, 1636-1642. 
1 Clavijo, A., E.M. Zhou, K. Hole, B. Galic, and P. Kitching, 2004: Development and use of a biotinylated 3ABC recombinant protein in a solid-phase competitive ELISA for the detection of antibodies against foot-and-mouth disease virus. J. Virol. Methods 120, 217-227.

Crowther, J.R., S. Farias, W.C. Carpenter, and A.R. Samuel, 1993: Identification of a fifth neutralizable site on type $\mathrm{O}$ foot-and-mouth disease virus following characterization of single and quintuple monoclonal antibody escape mutants. J. Gen. Virol. 74, 15471553.

Edgar, R.C, 2004: MUSCLE: multiple sequence alignment with high accuracy and high throughput. Nucleic Acids Res. 32, 1792-1797.

Felsenstein, J, 1985: Confidence limits on phylogenies: An approach using the bootstrap. Evolution 39, 783-791.

Grubman, M.J., and B. Baxt, 2004: Foot-and-mouth disease. Clin. Microbiol. Rev. 17, 465493.

Hamblin, C., I.T. Barnett, and J.R. Crowther, 1986a: A new enzyme-linked immunosorbent assay (ELISA) for the detection of antibodies against foot-and-mouth disease virus. II. Application. J. Immunol. Methods 93, 123-129.

Hamblin, C., I.T.R. Barnett, and R.S. Hedger, 1986b: A new enzyme-linked immunosorbent assay (ELISA) for the detection of antibodies against foot-and-mouth disease virus. I. Development and method of ELISA. J. Immunol. Methods 93, 115-121.

Have, P., and M.H. Jensen, 1983: Detection of antibodies to foot-and-mouth disease virus type O1 by enzyme linked immunosorbent assay (ELISA). Report of the Session of the Research Group of the Standing Technical Committee of the European Commission for the Control of Foot-and-Mouth Disease, Lelystad, Netherlands, 20-22 September, 1983 (Appendix VIII 44-51). 
1 Hedger, R.S., I.T.R. Barnett, D.V. Gradwell, and P. Travassos Dias, 1982: Serological tests for foot-and-mouth disease in bovine serum samples. Problems of interpretation. Rev. sci. tech. Off. int. Epiz. 1, 387-393.

Kalema-Zikusoka, G., R.G. Bengis, A.L. Michel, and M.H. Woodford, 2005: A preliminary investigation of tuberculosis and other diseases in African buffalo (Syncerus caffer) in Queen Elizabeth National Park, Uganda. Onderstepoort J. Vet. Res. 72, 145-151.

Kasambula, L., G.J. Belsham, H.R. Siegismund, V.B. Muwanika, A.R. Ademun-Okurut, and C. Masembe, 2012: Serotype identification and VP1 coding sequence analysis of footand-mouth disease viruses from outbreaks in eastern and northern Uganda in 2008/9.

Kitson, J. D., D. McCahon, and G.J. Belsham, 1990: Sequence analysis of monoclonal antibody resistant mutants of type $\mathrm{O}$ foot-and-mouth disease virus: evidence for the involvement

Knowles, N. J., and A. R. Samuel, 2003: Molecular epidemiology of foot-and-mouth disease virus. Virus Res. 91, 65-80.

Longjam, N., R. Deb, A.K. Sarmah, T. Tayo, V.B. Awachat, and V.K. Saxena, 2011: A brief review on diagnosis of foot-and-mouth disease of livestock: Conventional to molecular tools. Vet. Med. Int. DOI:10.4061/2011/905768

Mackay, D.K., A.N. Bulut, T. Rendle, F. Davidson, and N.P. Ferris, 2001: A solid-phase competition ELISA for measuring antibody to foot-and-mouth disease virus. J. Virol. Methods 97, 33-48.

Motulsky, H., 1995: Intuitive Biostatistics, Oxford University Press, USA. 
1 Muleme, M., R. Barigye, M.L. Khaitsa, E. Berry, A.W. Wamono, and C. Ayebazibwe, 2012: Effectiveness of vaccines and vaccination programs for the control of foot-and-mouth disease in Uganda, 2001-2010. Trop. Anim. Health Prod. 45, 35-43.

Mwiine, F.N., C. Ayebazibwe, S. Alexandersen, W. Olaho- Mukani, A.R. Okurut Ademun, and K. Tjornehoj, 2010a: Seroepidemiological investigation of foot-and-mouth disease virus serotypes in cattle around Lake Mburo National Park in South-western Uganda. J. Vet. Med. Anim. Health 2, 46-54.

Mwiine, F.N., C. Ayebazibwe, W. Olaho-Mukani, S. Alexandersen, S.N. Balinda, C. Masembe, A.R. Okurut, L.S. Christensen, K.J. Sorensen, and K. Tjornehoj, 2010b: Serotype specificity of antibodies against foot-and-mouth disease virus in cattle in selected districts in Uganda. Transbound. Emerg. Dis. 57, 365-374.

Mwiine, N.F., C. Ayebazibwe, W. Olaho-Mukani, S. Alexandersen, M. Ademun Okurut, and K. Tjornehoj, 2010c: Prevalence of antibodies against foot-and-mouth disease virus in cattle in Kasese and Bushenyi districts of Uganda. Inter. J. Anim. Vet. Advances 2, 8996.

Namatovu, A., S.N. Wekesa, K. Tjornehoj, M.T. Dhikusooka, V.B. Muwanika, H.R. Siegsmund, and C. Ayebazibwe, 2013: Laboratory capacity for diagnosis of foot-andmouth disease in Eastern Africa: implications for the progressive control pathway. BMC Vet. Res. 9, 19.

OIE, 2008: Biosafety and Biosecurity in the Veterinary microbiology laboratory and Animal facilities (Chapter 1.1.2).

http://www.oie.int/fileadmin/Home/eng/Health_standards/tahm/1.1.02_BIOSAFETY.pdf (Accessed 23/3/2013).

OIE, 2012: Foot-and-Mouth Disease. In: OIE Standards Commission editor. Manual of diagnostic tests and vaccines. [Chapter 2.1.5] 

(Accessed 3/5/2013).

Paixao, T.A., A.V. Neta, N.O. Paiva, J.R. Reis, M.S. Barbosa, C.V. Serra, R.R. Silva, T.R. Beckham, B.M. Martin, N.P. Clarke, L.G. Adams, and R.L. Santos, 2008: Diagnosis of foot-and mouth disease by real time reverse transcription polymerase chain reaction under field conditions in Brazil. BMC Vet. Res. 4, 53.

Reed, L.J., and H. Muench, 1938: A simple method of estimating fifty percent endpoints. Am. J. Hyg. 27, 493-497.

Reid, S.M., N.P. Ferris, G.H. Hutchings, Z. Zhang, G.J. Belsham, and S. Alexandersen, 2002: Detection of all seven serotypes of foot-and-mouth disease virus by real-time, fluorogenic reverse transcription polymerase chain reaction assay. J. Virol. Methods 105, 67-80.

Rutagwenda, T., 2003: The implications and consequences of foot and mouth disease outbreak on food security and household incomes in selected districts in Uganda; A draft consultancy report (Study report 2), FAO, Rome (Italy). Animal Production and Health Div. TCP/UGA/ 0168 (E) 1.

Rweyemamu, M., P. Roeder, D. Mackay, K. Sumption, J. Brownlie, Y. Leforban, J.F. Valarcher, N.J. Knowles, and V. Saraiva, 2008: Epidemiological patterns of foot-andmouth disease worldwide. Transbound. Emerg. Dis. 55, 57-72.

Saitou, N., and M. Nei, 1987: The neighbor-joining method: a new method for reconstructing phylogenetic trees. Mol. Biol. Evol. 4, 406-425.

Samuel, A.R., and N.J. Knowles, 2001: Foot-and-mouth disease type O viruses exhibit genetically and geographically distinct evolutionary lineages (topotypes). J. Gen. Virol. 82, 609-621. 
1 Sorensen, K.J., K. de Stricker, K.C. Dyrting, S. Grazioli, and B. Haas, 2005: Differentiation of foot-and-mouth disease virus infected animals from vaccinated animals using a blocking ELISA based on baculovirus expressed FMDV 3ABC antigen and a 3ABC monoclonal antibody. Arch. Virol. 150, 805-814.

Sorensen, K.J., K.G. Madsen, E.S. Madsen, J.S. Salt, J. Nqindi, and D.K. Mackay, 1998: Differentiation of infection from vaccination in foot-and-mouth disease by the detection of antibodies to the non-structural proteins 3D, 3AB and 3ABC in ELISA using antigens expressed in baculovirus. Arch. Virol. 143, 1461-1476.

Sutmoller, P., S.S. Barteling, R.C. Olascoaga, and K.J. Sumption, 2003: Control and eradication of foot-and-mouth disease. Virus Res. 91, 101-144.

Tamura, K., 1992: Estimation of the number of nucleotide substitutions when there are strong transition-transversion and G + C-content biases. Mol. Biol. Evol. 9, 678-687.

Tamura, K., D. Peterson, N. Peterson, G. Stecher, M. Nei, and S. Kumar, 2011: MEGA5: molecular evolutionary genetics analysis using maximum likelihood, evolutionary distance, and maximum parsimony methods. Mol. Biol. Evol. 28, 2731-2739.

Vosloo, W., N.J. Knowles, and G.R. Thomson, 1992: Genetic relationships between southern African SAT-2 isolates of foot-and-mouth disease virus. Epidemiol. Infect. 109, 547558.

Vosloo, W., A.D. Bastos, O. Sangare, S.K. Hargreaves, and G.R. Thomson, 2002: Review of the status and control of foot and mouth disease in sub-Saharan Africa. Rev. Sci. Tech. 21, 437-449.

Wekesa, S.N., V.B. Muwanika, H.R. Siegismund, A.K. Sangula, A. Namatovu, M.T. Dhikusooka, K. Tjørnehøj, S.N. Balinda, J. Wadsworth, N.J. Knowles, and G.J. Belsham, 2013: Analysis of recent serotype O foot-and-mouth disease viruses from 
livestock in Kenya: Evidence of four independently evolving lineages. Transbound. Emerg. Dis. In press . Doi:10.1111/tbed.12152

\section{Figure legends}

Figure 1. The study area.

The map shows the seven districts of Uganda that reported FMD outbreaks between January and April, 2011. These districts included; Bukedea and Kumi from the Eastern region, Gomba and Sembabule from the Central region, Isingiro and Kiruhura from the South- Western region and Rakai from the Southern region.

Figure 2. Neighbour-Joining Phylogeny tree based on VP1 coding sequences showing the relationship between Ugandan 2011 serotype $O$ and earlier East African serotype $O$ viruses. The four 2011 Ugandan and one 2010 Kenyan outbreak FMDV sequences are marked with asterisks $(*)$ and $\mathrm{O} / \mathrm{K} 77 / 78^{* *}$ is the serotype $\mathrm{O}$ virus strain incorporated in the trivalent vaccines (O, SAT 1 and SAT 2) used in Uganda. Bootstrap values larger than 50\% are depicted in the tree.

\section{Figure 3. Alignment of sixteen inferred amino acid sequences of the VP1 region from the} 2011 outbreak (marked with an asterisk (*)) and earlier East African serotype $O$ strains. The dots show identity with the consensus sequence O/K77/78** (the vaccine strain). Similar amino acid variations exist between the isolates U04/11 (Bukedea) and U19/11 (Kumi) while 
1 the U07/11 (Rakai) and U24/11 (Sembabule) viruses had unique differences within the region

2 150-153. The sequence of K251/2010 (Kwanza, Kenya) (Wekesa et al., 2013) differed from

$3 \mathrm{U}$ 04/11 and U19/11 by two amino acids at positions 96 and 168.

$7 \quad$ Table legends

8 Table 1. East African FMDV serotype $O$ sequences used for comparison in this study

9 *: the recent 2011 Ugandan and 2010 Kenyan FMDV outbreak sequences included in this study 10 and **: the FMDV strain incorporated in the trivalent vaccine currently used in Uganda.

Table 2. Detection of antibodies against non-structural and structural proteins of FMDV

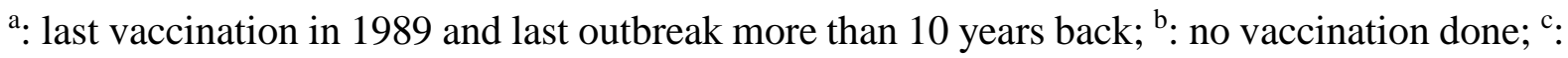

14 last vaccination in July/2010 and last outbreak in September/2009; d: Kr.2 herd vaccinated on

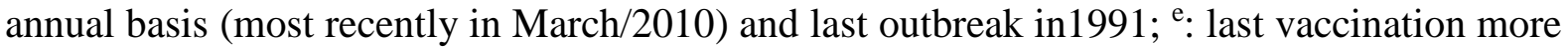
than 10 years back; ${ }^{\mathrm{f}}$ : no information on last vaccination and g: vaccination status unknown

Table 3. Comparative evaluation of SPBE and VNT assays for the detection of antibodies against structural proteins of FMDV in cattle in seven Ugandan districts with reported FMD outbreaks in 2011

$21 *$ : samples also positive in VNT for antibodies against serotype O FMDV. 


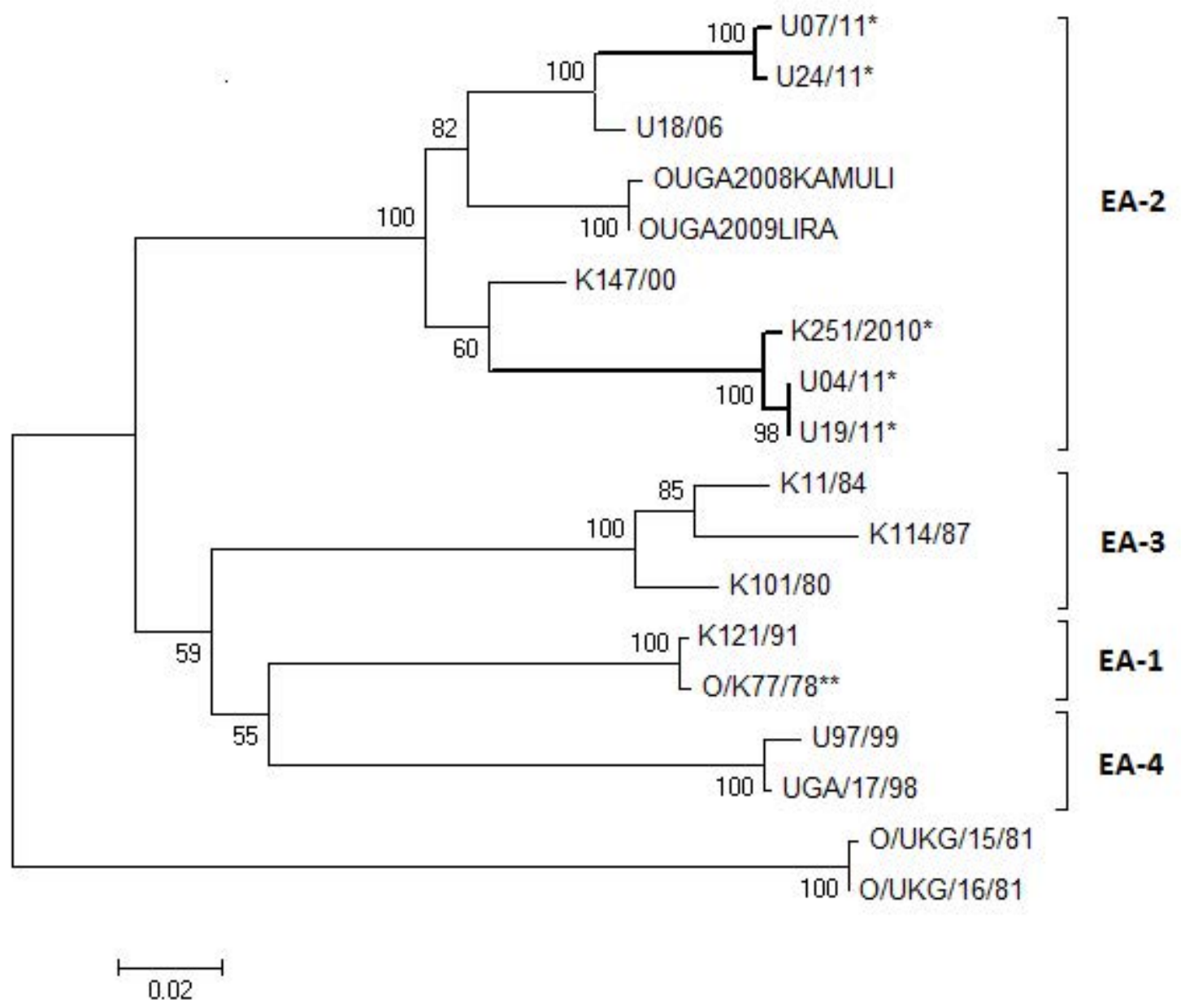


$0 / 377 / 78$. $\mathrm{x} 101 / 80$

$0 / \operatorname{tra} / 15 / 81$ $0 / \operatorname{tak} 6 / 16 / 81$

$\mathrm{K} 11 / \mathrm{B} 4$

$\mathrm{x} 114 / 87$

$\mathrm{K} 121 / 91$

$\mathrm{K} 147 / 00$

ए18/06

Otga2 o o arkavdr

OUCA200gLIRA

K251/2010*

$004 / 11 *$

ש19/11*

प07/11*

ข24/11*

$0 / 377 / 78+\infty$

$\mathrm{K} 101 / 80$

$0 / \operatorname{tra} / 15 / 81$

$0 / \operatorname{tax} 6 / 16 / 81$

$\mathrm{x} 11 / 84$

$\mathrm{x} 114 / 87$

X121/91

$\mathrm{X} 147 / 00$

ष18/06

ouca200axastr

OtUCA200ILIFA

X251/2010-

004/11*

ข19/11*

007/11*

v24/11*

20

30

40

50

60

70

80

90

100

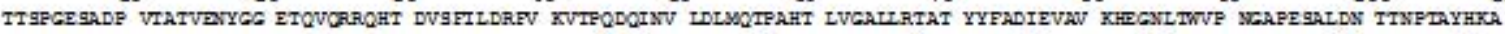

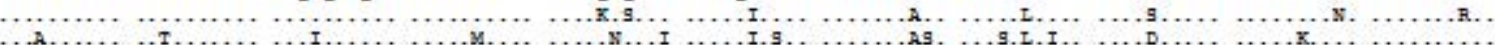

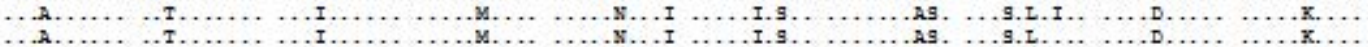

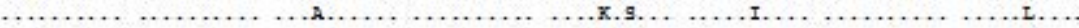

\begin{tabular}{|c|c|c|c|c|c|c|c|c|c|}
\hline & & 30 & & 5 & & 18 & & 200 & 10 \\
\hline IFTATEY & EHI & CxcFycas & DLd & 10 & $P$ & RVI & a & CLA? & 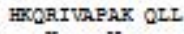 \\
\hline & $\ldots \ldots \ldots$ & ....2s. & $\ldots \ldots$ & ....... & $\ldots \ldots$ & $\ldots$ & 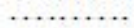 & $\cdots$ & - $\mathrm{s}$. \\
\hline .. & $\ldots \ldots$ & ...... & $\ldots$ & ... & $\cdots$ & - & $\cdots$ & 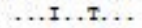 & $\ldots \mathrm{x}$. \\
\hline$\cdots$ & ........... & ...... S.XA & .P.I. . . . & $\cdots$ & * & $\ldots T$ & $\cdots \cdot$ & $\pi$ & $\mathrm{X}$ \\
\hline & $\cdots$ & $\ldots$. . . Kg. & $\cdots$ &.$A$ & * & $\cdots 1$ & & PII & $\ldots$ \\
\hline$\cdots$ & $\cdots$ & .D.X. KS. & $\cdots$ & $\cdots$ & - & $\cdots$ & ....... & $\ldots$ & 7. \\
\hline$\cdots$ & . & $\cdots$ & $\cdots$ & $\cdots$ & & 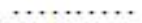 & * & & \\
\hline & & 9 & & . & & $\cdot 2$ & & $\cdots$ & $\cdots$ \\
\hline & $\cdots$ & .......9Ggs & A. & $\cdots$ & $\cdots$ & $\ldots \mathrm{T}$ & . & $\cdots$ & v. \\
\hline & $\cdots$ & .......9Dgg & A. . & $\cdots$ & & $\ldots \mathrm{T}$ & . & D. . & $\ldots x$ \\
\hline & $\begin{array}{l}\cdots \\
0\end{array}$ & ....... gDgs & A... & $\cdots$ & & $\ldots \mathrm{T}$ & .. & $\cdots$ & $\ldots \mathrm{x}$ \\
\hline & $\cdots$ & ......s & .. & $\cdots$ & $\ldots \ldots \ldots v$. &. $\mathrm{T}$ & . & $\ldots$ & .2 \\
\hline & $\cdots$ & 9. & . & - & & $\mathrm{T}$ & $\cdots$ & $\cdots$ & .8 \\
\hline & $\cdots$ & 9. & $\cdots$ & $=\mathrm{A}$ & $\cdots \ldots \ldots \ldots$ &. $\mathrm{T}$ & $\ldots \ldots$ & $\cdots \cdots$ & $\cdots x$. \\
\hline & & a. & $\cdots$ & $\cdot$ & $\cdots$ & & $\cdots$ & & $\mathrm{v}$. \\
\hline
\end{tabular}


Table 1. East African FMDV serotype $O$ sequences used for comparison in this study

\begin{tabular}{|c|c|c|c|c|c|}
\hline Reference Number & $\begin{array}{l}\text { Date of } \\
\text { collection }\end{array}$ & Area/ country & $\begin{array}{l}\text { Accession } \\
\text { number }\end{array}$ & $\begin{array}{l}\text { Topo } \\
\text { type }\end{array}$ & Reference \\
\hline U04/11* & $04 / 3 / 2011$ & Bukedea, Uganda & KF478938 & EA-2 & this study \\
\hline U19/11* & 04/3/2011 & Kumi, Uganda & KF478940 & EA-2 & this study \\
\hline \multirow[t]{2}{*}{$\mathrm{U} 24 / 11^{*}$} & 09/3/2011 & Sembabule, & KF478941 & EA-2 & this study \\
\hline & & Uganda & & & \\
\hline U07/11* & $01 / 4 / 2011$ & Rakai, Uganda & KF478939 & EA-2 & this study \\
\hline \multirow[t]{2}{*}{ K251/2010* } & $29 / 12 / 201$ & Kwanza, Kenya & KF207887 & EA-2 & (Wekesa et al., 2013) \\
\hline & 0 & & & & \\
\hline OUGA2009 Lira & 2009 & Lira, Uganda & JN974308 & EA-2 & (Kasambula et al., 2012) \\
\hline OUGA2008 & 2008 & Kamuli, Uganda & JN974312 & EA-2 & (Kasambula et al., 2012) \\
\hline \multicolumn{6}{|l|}{ Kamuli } \\
\hline \multirow[t]{2}{*}{ U18/06 } & 2006 & Mpigi, Uganda & HM75662 & EA-2 & (Balinda et al., 2010b) \\
\hline & & & 7 & & \\
\hline \multirow[t]{2}{*}{ K147/00 } & 2000 & Trans Nzoia, Kenya & HM75661 & EA-2 & (Balinda et al., 2010b) \\
\hline & & & 2 & & \\
\hline \multirow[t]{2}{*}{ U97/99 } & 1999 & Uganda & HM75660 & EA-4 & (Balinda et al., 2010b) \\
\hline & & & 4 & & \\
\hline \multirow[t]{2}{*}{$\mathrm{K} 121 / 91$} & 1991 & Kiambu, Kenya & HM75659 & EA-1 & (Balinda et al., 2010b) \\
\hline & & & 5 & & \\
\hline \multirow[t]{2}{*}{ O/UGA/17/98 } & 1998 & Uganda & HM21107 & EA-4 & (Ayelet et al., 2009) \\
\hline & & & 5 & & \\
\hline \multirow[t]{2}{*}{ K114/87 } & 1987 & Kiambu, Kenya & HM75659 & EA-3 & (Balinda et al., 2010b) \\
\hline & & & 4 & & \\
\hline \multirow[t]{2}{*}{ K11/84 } & 1984 & Kiambu, Kenya & HM75659 & EA-3 & (Balinda et al., 2010b) \\
\hline & & & 1 & & \\
\hline K101/80 & 1980 & Laikipia, Kenya & $\begin{array}{l}\text { HM75658 } \\
9\end{array}$ & EA-3 & (Balinda et al., 2010b) \\
\hline $\mathrm{O} / \mathrm{K} 77 / 78^{* *}$ & 1998 & Kenya & $\begin{array}{l}\text { DQ16507 } \\
2\end{array}$ & EA-1 & (Balinda et al., 2010b) \\
\hline O/UKG/15/81 & 19/3/1981 & Jersey, UK & JX869193 & ME-SA & $\begin{array}{l}\text { Wright et al., } \\
\text { (Unpublished ) }\end{array}$ \\
\hline O/UKG/16/81 & 21/3/1981 & Isle of Wight, UK & JX869194 & ME-SA & $\begin{array}{l}\text { Wright et al., } \\
\text { (Unpublished) }\end{array}$ \\
\hline
\end{tabular}


*: the recent 2011 Ugandan and 2010 Kenyan outbreak FMDV sequences included in this study and**: the FMDV strain incorporated in the trivalent vaccine currently used in Uganda. 
Table 2. Detection of antibodies against non-structural and structural proteins of FMDV

\begin{tabular}{|c|c|c|c|c|c|c|c|c|c|}
\hline \multirow[t]{2}{*}{$\begin{array}{c}\text { Samples/ } \\
\text { Origin }\end{array}$} & \multirow[t]{2}{*}{$\begin{array}{l}\text { No. of } \\
\text { sera }\end{array}$} & \multirow[t]{2}{*}{$\begin{array}{l}\text { NSP } \\
\text { Positive }\end{array}$} & \multicolumn{7}{|c|}{$\begin{array}{l}\text { Proportion of NSP positive sera with evidence of antibodies } \\
\text { against the different serotypes using SPBEs ( titre } \geq 80 \text { ) }\end{array}$} \\
\hline & & & $\mathrm{O}$ & A & $\mathrm{C}$ & Asia 1 & SAT 1 & SAT 2 & SAT 3 \\
\hline \multicolumn{10}{|l|}{ 1. cattle } \\
\hline \multicolumn{10}{|l|}{ Bukedea $^{\mathrm{a}}$} \\
\hline & 10 & 6 & $3 / 6$ & $0 / 5$ & $0 / 6$ & $0 / 6$ & $4 / 6$ & $0 / 6$ & $3 / 6$ \\
\hline \multicolumn{10}{|l|}{ Bk.1 } \\
\hline \multicolumn{10}{|l|}{ Gomba $^{b}$} \\
\hline Gb.1 & 15 & 3 & $0 / 3$ & $0 / 3$ & $0 / 3$ & $0 / 3$ & $0 / 3$ & $0 / 3$ & $0 / 3$ \\
\hline Gb.2 & 16 & 6 & $1 / 4$ & $0 / 4$ & $0 / 4$ & $0 / 4$ & $3 / 5$ & $0 / 5$ & $1 / 5$ \\
\hline Sub total & 31 & 9 & $1 / 7$ & $0 / 7$ & $0 / 7$ & $0 / 7$ & $3 / 8$ & $0 / 8$ & $1 / 8$ \\
\hline \multicolumn{10}{|l|}{ Isingiro $^{C}$} \\
\hline Is.1 & 20 & 18 & $12 / 16$ & $0 / 16$ & $0 / 15$ & $0 / 17$ & $5 / 18$ & $0 / 17$ & $2 / 16$ \\
\hline \multicolumn{10}{|l|}{ Kiruhurad $^{d}$} \\
\hline Kr.1 & 11 & 5 & $0 / 4$ & $0 / 4$ & $0 / 4$ & $0 / 4$ & $0 / 4$ & $0 / 4$ & $0 / 4$ \\
\hline Kr.2 & 6 & 5 & $3 / 5$ & $1 / 5$ & $1 / 5$ & $0 / 5$ & $4 / 5$ & $3 / 5$ & $4 / 5$ \\
\hline Sub total & 17 & 10 & $3 / 9$ & $1 / 9$ & $1 / 9$ & $0 / 9$ & $4 / 9$ & $3 / 9$ & $4 / 9$ \\
\hline \multicolumn{10}{|l|}{$\mathrm{Kumi}^{\mathrm{e}}$} \\
\hline Km.1 & 3 & 3 & $0 / 3$ & $0 / 3$ & $0 / 3$ & $0 / 3$ & $2 / 3$ & $0 / 3$ & $2 / 3$ \\
\hline $\mathrm{Km} .2$ & 35 & 21 & $9 / 21$ & $2 / 21$ & $0 / 21$ & $0 / 21$ & $6 / 20$ & $0 / 21$ & $4 / 17$ \\
\hline Sub total & 38 & 24 & $9 / 24$ & $2 / 24$ & $0 / 24$ & $0 / 23$ & $8 / 23$ & $0 / 24$ & $6 / 20$ \\
\hline \multicolumn{10}{|l|}{ Rakaif $^{f}$} \\
\hline Rk.1 & 13 & 13 & $10 / 11$ & $1 / 11$ & $0 / 13$ & $0 / 11$ & $3 / 12$ & $1 / 13$ & $1 / 13$ \\
\hline Rk.2 & 9 & 4 & $3 / 4$ & $1 / 3$ & $0 / 4$ & $0 / 4$ & $3 / 4$ & $0 / 4$ & $1 / 4$ \\
\hline Rk.3 & 11 & 11 & $8 / 9$ & $2 / 9$ & $2 / 11$ & $1 / 10$ & $8 / 11$ & $6 / 11$ & $6 / 11$ \\
\hline Sub total & 33 & 28 & $21 / 24$ & $4 / 23$ & $2 / 28$ & $1 / 25$ & $14 / 27$ & $7 / 28$ & $8 / 28$ \\
\hline \multicolumn{10}{|l|}{ Sembabule $^{g}$} \\
\hline Sb.1 & 31 & 4 & $1 / 3$ & $0 / 3$ & $0 / 3$ & $0 / 3$ & $1 / 3$ & $0 / 3$ & $0 / 3$ \\
\hline Sb.2 & 5 & 1 & $0 / 1$ & $0 / 1$ & $0 / 1$ & $0 / 1$ & $0 / 1$ & $0 / 1$ & $0 / 1$ \\
\hline Sb.3 & 21 & 6 & $0 / 6$ & $0 / 6$ & $0 / 6$ & $0 / 6$ & $0 / 6$ & $0 / 6$ & $0 / 5$ \\
\hline Sb.4 & 12 & 3 & $0 / 3$ & $0 / 3$ & $0 / 3$ & $0 / 3$ & $0 / 3$ & $0 / 3$ & $0 / 3$ \\
\hline Sub total & 69 & 14 & $1 / 13$ & $0 / 13$ & $0 / 13$ & $0 / 13$ & $1 / 13$ & $0 / 13$ & $0 / 12$ \\
\hline Total & 218 & 109 & $50 / 99$ & $7 / 97$ & $3 / 103$ & $1 / 100$ & $39 / 10$ & $10 / 10$ & $24 / 99$ \\
\hline & & $(50 \%)$ & (51\%) & $(7 \%)$ & $(3 \%)$ & $(1 \%)$ & $\begin{array}{l}4 \\
(38 \%)\end{array}$ & $\begin{array}{l}5 \\
(10 \%)\end{array}$ & $(24 \%)$ \\
\hline
\end{tabular}

2. Goats

Bukedea

Gomba

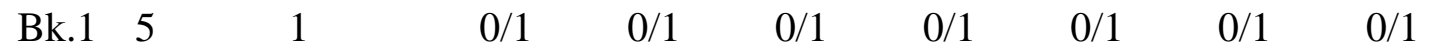

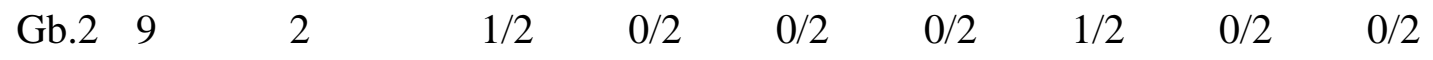

Kumi

\begin{tabular}{rlllllllll} 
Km.1 & 3 & 1 & $0 / 1$ & $0 / 1$ & $0 / 1$ & $0 / 1$ & $0 / 1$ & $0 / 1$ & $0 / 1$ \\
Km.2 & 6 & 0 & - & - & - & - & - & - & - \\
\hline Total & 23 & $4(17 \%)$ & $1 / 4$ & $0 / 4$ & $0 / 4$ & $0 / 4$ & $1 / 4$ & $0 / 4$ & $0 / 4$ \\
\hline
\end{tabular}

a: last vaccination in 1989 and last outbreak more than 10 years back; ${ }^{\text {b}}$ : no vaccination done; ${ }^{\text {c: }}$

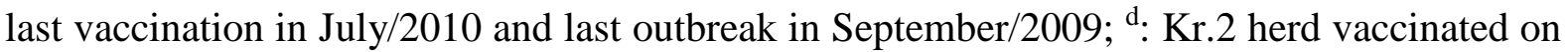


annual basis (most recently in March/2010) and last outbreak in1991; e. last vaccination more

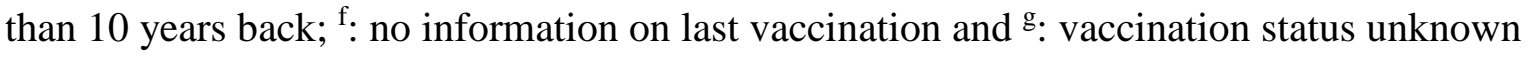


Table 3. Comparative evaluation of SPBE and VNT assays for the detection of antibodies against structural proteins of FMDV in cattle in seven Ugandan districts with reported FMD outbreaks in 2011

\begin{tabular}{|c|c|c|c|c|c|c|c|c|c|c|c|c|c|c|c|c|c|c|c|}
\hline \multirow[t]{3}{*}{$\begin{array}{l}\text { Samples/ } \\
\text { origin }\end{array}$} & \multirow[t]{3}{*}{$\begin{array}{l}\text { NSP } \\
+\end{array}$} & \multicolumn{6}{|c|}{$\begin{array}{l}\text { SPBE and VNT results for Serotypes } \\
\text { O }\end{array}$} & \multicolumn{6}{|c|}{ SPBE and VNT results for Serotypes SAT 1} & \multicolumn{6}{|c|}{$\begin{array}{l}\text { SPBE and VNT results for Serotypes } \\
\text { SAT } 3\end{array}$} \\
\hline & & \multirow[t]{2}{*}{$\begin{array}{l}\text { SPBE- } \\
\mathrm{O}+\end{array}$} & \multirow[t]{2}{*}{$\begin{array}{c}\text { VNT- } \\
\mathrm{O}+\end{array}$} & \multicolumn{4}{|c|}{$\begin{array}{l}\text { SPBE-O/VNT }-\mathrm{O} \\
\text { results }\end{array}$} & \multirow[t]{2}{*}{$\begin{array}{l}\text { SPBE- } \\
\text { SAT } 1+\end{array}$} & \multirow[t]{2}{*}{$\begin{array}{l}\text { VNT- } \\
\text { SAT } 1+\end{array}$} & \multicolumn{4}{|c|}{$\begin{array}{l}\text { SPBE-SAT } 1 / \mathrm{VNT}- \\
\text { SAT } 1 \text { results }\end{array}$} & \multirow{2}{*}{$\begin{array}{c}\text { SPBE } \\
\text {-SAT } \\
3\end{array}$} & \multirow[t]{2}{*}{$\begin{array}{l}\text { VNT- } \\
\text { SAT } 3\end{array}$} & \multicolumn{4}{|c|}{$\begin{array}{l}\text { SPBE-SAT } 3 / \mathrm{VNT}- \\
\text { SAT } 3 \text { results }\end{array}$} \\
\hline & & & & $+/+$ & $+/$ & $-/+$ & $-/-$ & & & $+/+$ & $+/-$ & $-/+$ & $-/-$ & & & $+/+$ & $+/$ & $-/+$ & $-/-$ \\
\hline Bukedea & 6 & 3 & 4 & 3 & - & 1 & 2 & 4 & 0 & - & 4 & - & 2 & 3 & 0 & - & 3 & - & 3 \\
\hline Gomba & 1 & 1 & 0 & - & 1 & - & - & 1 & 0 & - & 1 & - & - & 0 & 0 & - & - & - & 1 \\
\hline Isingiro & 8 & 8 & 7 & 7 & 1 & - & - & 3 & 0 & - & 3 & - & 5 & 1 & 0 & - & 1 & - & 7 \\
\hline Kiruhura & 4 & 3 & 2 & 2 & 1 & - & 1 & 4 & 1 & $1 *$ & 3 & - & - & 4 & 0 & - & 4 & - & - \\
\hline Kumi & 20 & 9 & 16 & 8 & 1 & 8 & 3 & 8 & 0 & - & 8 & - & 12 & 8 & 1 & $1 *$ & 7 & - & 12 \\
\hline Rakai & 19 & 18 & 19 & 18 & - & 1 & - & 12 & 0 & - & 12 & - & 7 & 6 & 0 & - & 6 & - & 13 \\
\hline Sembabule & 14 & 1 & 1 & 1 & - & - & 13 & 1 & 0 & - & 1 & - & 13 & 0 & 0 & - & - & - & 14 \\
\hline Total & 72 & $\begin{array}{l}43 \\
(60 \%)\end{array}$ & $\begin{array}{l}49 \\
(68 \%)\end{array}$ & 39 & 4 & 10 & 19 & $\begin{array}{l}33 \\
(46 \%)\end{array}$ & $\begin{array}{l}1 \\
(1.4 \%)\end{array}$ & 1 & 32 & 0 & 39 & $\begin{array}{l}22 \\
(31 \%)\end{array}$ & $\begin{array}{l}1 \\
(1.4 \%)\end{array}$ & 1 & 21 & 0 & 50 \\
\hline
\end{tabular}

*: Samples also positive in VNT for antibodies against serotype O FMDV 